\title{
KLEIN DISKUSSIE
}

Prof. J. H. van Wyk, skryf hierdie keer iets oor wat hy voorlopig "wedersydse ekskommunikasie" noem, 'n ou maar verwoestende vraagstuk wat die Christendom in 'n groot mate lamlê en wat in die jongste tyd weer skerp na vore gekom het. Hy hoop om die vraagstuk aan die hand van enkele eietydse voorbeeide toe te lig.

\section{SUID-AFRIKA en NEDERLAND}

Dit is oorbekend dat daar lank spanninge tussen die GKSA en die GKN was - en tans nog in die GES is - en dat hierdie spanninge in 1976 tot 'n breuk in kerklike gemeenskap gelei het toe die GKSA die gemeenskap opgesê het. Dit is interessant om daarop te let dat terwyl die GKSA die GKN van dogmatiese dwaling (Skrifleer, versoeningsleer) beskuldig het, die GKN weer die GKSA oor etiese dwalinge (apartheid) aangespreek het.

Hoe die twee standpunte teenoor mekaar staan, word deur die volgende twee (ekskommunikerende) uitsprake weerspieël, een uit SA en een uit Nederland.

Uit SA word soos volg oor die breuk van 1976 geoordeel: "In wese kom die (verbroke korrespondensie) daarop neer dat verklaar is dat die GKN die ware belydenis verloën het en deur verharding daarom, ten spyte van vermaning, nou as heiden en tollenaar beskou word" (1983).

Hierteenoor sê 'n stem uit Nederland: "Er zijn dingen die eenvoudigweg niet kunnen: fascist zijn of rassist of stalinist is immoreel en dus onaanvaarbaar binnen de christelijke gemeente - Er bestaat politiek - ik bedoel er praktische politiek mee - waaraan christenen niet kunnen meedoen zonder hun status van christenen in de waagschaal te stellen. Politieke programma's - we zouden het over praktische politiek hebben - die de uitroeiing van Joden, het vogelvrij verklaren van homofielen, het doden van politieke tegenstanders of het ontnemen van politieke rechten aan zwarten en kleurlingen in hun vaandel geschreven hebben, zijn onmenselijke programma's en christenen die aan zulke programma's steun verlenen of aan regiems, die dergelijke programma's uitvoeren, moeten van hun christennaam vervallen worden verklaard. Rechtvaardigen ze zulke praktijken met een beroep op Gods wil of Gods inzettingen, dan moet je zelfs van blasfemie spreken" (1981).

\section{SUID-AFRIKA en SUID-AFRIKA}

Om nader tuis te kom en aan te haal uit debatte wat rondom die Referendum 1983 gevoer is:

Die denklyn van een redenaar is soos volg (en dit is bedoel as kritiek teen die nuwe grondwet, dus vir 'n nee-stem): "Ons sal eers die gebed wat ons Here Jesus aan ons geleer het, moet verander, of die Ontwerp-Grondwet van die Republiek van Suid-Afrika moet verwerp". En in dieselfde lyn: "Die nuwe grondwet... verbeur ... alle 
aanspraak op Christelike en Bybelse motiewe"; "magsdeling met groepe wat die Bybelse grondwaarhede verwerp, is (op grond van art 36 NGB) prinsipieel onmoontlik".

Hierteenoor die volgende stem, ten gunste van 'n ja: "Dit is nie maar om't ewe of ons ja of nee (nee in regse sin) gaan stem in die referendum nie. Versoening is 'n begrip uit die hart van die evangelie, uit die Hart van God. In die referendum gaan ons stem oor die weg van daadwerklike versoening in ons politiek. Wie daarvoor gaan nee sê, gaan nee sê vir God. Dis hier waar Paulus se woorde te pas kom en die gesante van God in die mond gelê word teenoor die weerbarstiges: 'Ons bid julle om Christus wil: Laat julle met God versoen' ( 2 Kor. 5 :20)."

In dieselfde rigting beweeg die volgende gedagte: "Daar is ook goeie rede waarom Christene nie met die argumente vir die neestem kan saamstem nie. Hierdie argumente maak die gevaar groot dat selfsug tot die hoogste beginsel in die openbare lewe verhef sal word. Dit is regstreeks in stryd met Christelike beginsels en baie nadelig vir ons samelewing. Dit is ook in stryd met die koningskap van Christus oor ons openbare lewe".

Nog weer 'n ander stem, die keer vir 'n ander soort nee: "Om "Christus Koning te laat wees" beteken om Hom na te volg in sy aanvaarding van die onaanvaarde, die verstoteling, die vreemdeling, die magtelose. Om 'n groep medeburgers te verag of van gemeenskaplike besluitnemingsprosesse uit te sluit, is vreemd aan die Gees van Christus ... Verwerping (van swartes) skep wanhoop, bitterheid en 'n gees van wraak. As sodanig weerspreek dit politieke wysheid. Wat belangriker is, dit weerspreek Christelike liefde. 'n Christen is deur God in Christus aanvaar ten spyte van sy onwaardigheid. 'n Christen is geroepe om 'n werktuig van Christus se aanvaarding van die ander persoon te wees ten spyte van sy onaanvaarbaarheid. 'n Christen staan vir versoening en genesing... 'n Christen kan desnoods onder 'n diktatuur leef en daaronder ly, omdat hy aandeel het aan die Kruis van Christus. Maar 'n Christen kan nie deelneem nie aan 'n poging om die lyding van 'n diktatuur op ander mense af te dwing nie".

Ek evalueer nie hierdie (veral laaste) verskillende Christelike stemme hier nie maar sinjaleer net hierdie - diep tragiese - probleem. Ons probleem is nie soseer die van 'n swyende kerk en Christendom nie maar die van 'n mekaar weersprekende kerk en Christendom, waar nie net die geloofwaardigheid van die kerk nie maar dié van die evangelie self op die spel staan. Watter indruk moet so 'n verdeelde Christendom op die wêreld maak? Hoe kan die wêreld ooit die boodskap van die kerk en Christene ernstig neem as daar so baie - weersprekende - boodskappe is?

\section{OPLOSSING?}

Is daar 'n antwoord op hierdie probleem? Seker nie 'n finale nie. Tog wil ons graag 'n paar opmerkings hieroor maak.

Ten eerste moet die verskillende interpretasies, nié van die evangelie nie maar van die toépassing van die evangelie op die werklikheid, ons baie meer beskeie maak. Ons moet versigtig wees om 
sommerso ons (politieke) insigte as dié waarheid voor te hou. Hiermee is natuurlik nie beweer dat indien ons inderdaad oortuig is van die waarheid van 'n saak ons daaroor moet swyg nie!

Ten tweede moet ons veel meer $l y$ oor ons teenstellende interpretasies en standpunte. Ons moet werklik berou hê oor ons gebrek aan insig en eenstemmigheid. Dit is ver weg van 'n Christelike lewenstyl om lighartig en oppervlakkig om te spring met so 'n bedroewende stand van sake.

Ten derde moet hierdie probleem ons uitdryf tot veel meer gebed. Blykbaar is die leiding van die Gees in die hele waarheid nie sommer 'n outomatiese waarborg wat alle menslike worsteling vir die waarheid uitsluit nie.

Ten vierde sou ek daarvoor wou pleit dat studiedeputate van dic verskillende kerkgroepe veel meer moet probeer saamwerk met dic oog op eensluidende rapporte aan die verskillende sinodes. As ons in 'n groot saak soos Bybelvertaling kan saamwerk, waarom dan nie ook in 'n saak soos Bybelvertolking nie? Onmisbaar is veral die samewerking tussen wit, bruin en swart Christene. Alleen "saam met al die heiliges" leer ons die liefde van Christus ken (Efes $3: 18$ ).

Hiermee is enersluidende sieninge en uitsprake, veral oor lewensbelangrike sake, natuurlik nie vanself gegee nie, maar hiermee het ons darem 'n eerste tree gegee om die miswolke van uitsigloosheid op te klaar. Want dit is natuurlik waar dat al sou alle kerke weer een word, onderlinge meningsverskil nie sommerso sal verdwyn nie - nié dat dit in élke geval moêt verdwyn nie, 1 Kor. 11 : 19. Kerkeenheid waarborg nie enersdenkendheid. Wat ondertussen van elkeen gevra word is om te beproéf wat die Hére welbehááglik is (Efes $5: 10)$. 